(3)

Volume 21, 2018

\title{
Dialogue and THE CREATION OF TRANSFormative SOCIAL CHANGE: THE CASE OF SOCIAL ENTERPRISES
}

\author{
Chitvan Trivedi* Gettysburg College, Gettysburg, PA, USA ctrivedi@gettysburg.edu \\ Shalini Misra Virginia Tech, Alexandria, VA, USA shalini@,vt.edu
}

* Corresponding author

ABSTRACT

Aim/Purpose To understand the process of social change creation in social entrepreneurial ventures (SEVs), specifically emphasizing the role and nature of the communicative process in social change creation.

Background Drawing on data from seven SEVs from India and the US and employing a grounded theory methodology, this research scrutinizes the social change process and uncovers the role and characteristics of dialogue in this process.

Methodology Qualitative data was collected from seven social entrepreneurial organizations over a period of eight months from July 2011 to February 2012. Semistructured interviews were conducted with a wide range of members within these social entrepreneurial organizations $(n=27)$ with additional informal interviews with field workers and volunteers. Data from the semi-structured interviews and notes from observations were integrated with analyses of archival resources.

Contribution There is little scholarship about the process of social change creation and the necessary conditions to promote social change over time. Understanding the process of social change creation and the individual, interpersonal, and organizational conditions that facilitate the process is central to design of effective trans-sector TD problem solving ventures. This paper focuses on the process of social change creation in social entrepreneurial settings, specifically emphasizing the role and nature of the communicative process in social change creation.

Findings The reflections and experiences of the members of SEVs revealed that social entrepreneurship is a collective endeavor and this collective character is essential to its success. Collective organization and synergy, deep intra-

This paper is one in a Special Series on Transdisciplinary Communication

Accepting Editor Gaetano Lotrecchiano | Received: October 19, 2017 | Revised: March 17, April 5, 2018 | Accepted: April 9, 2018.

Cite as: Trivedi, c., \& Misra, S. (2018). Dialogue and the creation of transformative social change: The case of social enterprises. Informing Science: the International Journal of an Emerging Transdiscipline, 21, 107-132. https://doi.org/10.28945/4012

(CC BY-NC 4.0) This article is licensed to you under a Creative Commons Attribution-NonCommercial 4.0 International License. When you copy and redistribute this paper in full or in part, you need to provide proper attribution to it to ensure that others can later locate this work (and to ensure that others do not accuse you of plagiarism). You may (and we encourage you to) adapt, remix, transform, and build upon the material for any non-commercial purposes. This license does not permit you to use this material for commercial purposes. 
organizational communication, and a conducive organizational context are critical for the creation of collective wisdom and knowledge networks for longterm collaborative community capacity building. Dialogue emerged as a central category linking the other categories to explain the process of social change creation. Organic organizational structure enables knowledge creation and integration through the process of organizational learning through deep and continuous social interaction, or dialogue.

Recommendations This research elucidated the key characteristics of the organizational context for Practitioners required to support the creation of social change. It also identified the critical role and characteristics of the communicative process required to generate structural knowledge and collective wisdom at the organizational level.

Recommendations For individual and organizational learning, trans-sector transdisciplinary organfor Researchers izations require an appropriate organizational context. Key elements of such an and Society organizational context include (1) understanding the ecology of the social problem; (2) organic organizational structure; (3) continuous and deep social interaction among all levels of the organization; (4) employee and community autonomy and empowerment, and (5) attention to subtle environmental changes in the system. These elements in combination lead to the creation of collective wisdom. Collective wisdom then feeds back into the conception, planning, and action stages of the iterative cycle of organizational knowledge creation to create positive social change.

Future Research Future research model theoretically and study empirically the ecology of social entrepreneurship and trans-sector TD problem solving more broadly. For example, the ways in the personal attributes of social entrepreneurs (e.g., their leadership style, networking abilities) combine with circumstances at organizational, institutional, and international levels to influence the effectiveness of their efforts to promote positive social change within local and global communities. Second, the grounded theoretical framework developed here should be further refined and elaborated through the identification of additional key contextual factors that affect SEVs' capacity to promote positive social change and to achieve sustainability in different socioenvironmental contexts. There is also a need to translate the findings from this research to facilitate the creation of more inclusive problem solving contexts and practices.

Keywords social entrepreneurship, social change, transdisciplinary collaboration, communication, dialogue, complex problem solving

\section{INTRODUCTION}

Transformative and sustained social change remains elusive despite unprecedented efforts by transnational development institutions like the United Nations, federal and local governments, and the social sector to tackle global problems like extreme poverty, hunger, and disease. At the UN Millennium Development Summit in the year 2000, world leaders took stock of global challenges and proposed eight goals as a blueprint for the world's countries and leading development institutions to drastically mitigate the most pressing societal challenges of our time by the year 2015 and create transformative social change (e.g., reducing extreme poverty by $50 \%$, providing universal primary education). These Millennium Development Goals (MDG) spurred unprecedented efforts by governments and the social sector to tackle these problems. By 2015, while there was progress on all of the indicators based on the MDG targets, most goals were not achieved (Galatsidas \& Sheehy, 2015; United Nations, 2015). In its progress report on the Millennium Development Goals (MDGs), the 
UN identified four critical limitations in governmental and institutional approaches to addressing societal problems and creating social change. These were (1) inadequate emphasis on the role of local government participation in the problem solving process; (2) lack of diversity of stakeholders in the problem solving process and insufficient understanding of the relationships among them; (3) weak institutional capacity because of lack of diversity of participants from diverse sectors (government, civil society, business); and (4) a deficit of culturally sensitive and contextually compatible approaches to societal problems (United Nations Development Group, 2014).

A large body of research has similarly identified the critical importance of participatory and culturally sensitive approaches, the need for building institutional capacity through inter-sectoral partnerships, including partnerships with the private sector, and participatory monitoring and accountability in solving complex societal problems (Austin, 2000; Barringer \& Harrison, 2000; Bovaird, 2004; Child \& Faulkner, 1998; Peredo \& Chrisman, 2006). Other research has uncovered implicit prerequisite conditions entrenched in these approaches, such as the reliance on long term external funding and political commitment to institute structural and policy changes (Trivedi, 2010). For example, scores of NGOs work with communities to improve personal and public health through personal and home hygiene education. Nevertheless, their success rates are low as personal health is closely tied to sanitary conditions of the community. Structural conditions such as the lack of proper sewage disposal systems seriously undermine their efforts in health promotion and disease prevention (UN News Center, 2013).

Despite the broad scope of this literature, there is little scholarship about the process of social change creation and the necessary conditions to promote social change over time. This paper focuses on the process of social change creation in a specific type of complex problem solving organization, namely social entrepreneurial ventures (SEVs), with an emphasis on the role and nature of the communicative process in social change creation. We address two primary questions: What is the process of social change creation in trans-sector TD problem solving organizations? What contextual conditions support the process of social change creation? In the following sections, we define trans-sector transdisciplinary problem solving and social entrepreneurship, and summarize the literature on social change creation in the context of social entrepreneurial ventures to provide background and context for the present research.

\section{SOCIAL ENTREPRENEURSHIP AND TRANS-SECTOR TransDisciplinary PROBLEM SOLVING}

In recent decades, the potential of social entrepreneurship for addressing intractable societal problems has gained tremendous momentum throughout the world evidenced by large investments in social entrepreneurial ventures by foundations such as Ashoka, Schwab, and Skoll (Ashoka,n.d.; Schwab Foundation, n.d.; Skoll Foundation, n.d.). Because of their unique combination of private structure and public purpose, their generally smaller scale, connections to citizens, flexibility and capacity to tap private initiative in support of public purposes, social entrepreneurial ventures (SEVs) have surfaced as strategically important potential partners in the effort to forge new solutions to existing social problems (Trivedi \& Stokols, 2011).

SEVs are collaborative and participatory organizational forms whose goal is to address long standing social problems and facilitate sustained positive social change (Trivedi \& Stokols, 2011). Included among the objectives of such organizations are providing goods and services that the market or public sector is either unwilling or unable to provide, developing skills, creating employment, and fostering pathways for the integration of socially excluded people (Martin \& Osberg, 2015; Trivedi, 2010; Trivedi \& Stokols, 2011). In fact, recognized social needs, market failure and repeated unsuccessful attempts by the government to address socio-environmental problems are the primary reasons for the existence of SEVs. While SEVs can provide private means to pursue public good, their core aim is to address 
deep-rooted social problems and social injustice, reverse societal imbalance, and transform the structural and political system through processes of social change creation and sustenance.

SEVs are characterized by a particular type of trans-sector transdisciplinary (TD) problem solving (Klein, 2010) in which a diversity of members, organizations, and stakeholders contribute knowledge, skills, expertise, and other resources and cooperate for democratic and holistic solutions to societal problems (TD Net, 2009). While one strand of trans-sector TD problem solving centers on academic collaborations between universities and industrial/private sectors to address scientific or translational problems, SEVs are characterized by a different type of TD problem solving. Here members from different sectors of society (including academia, non-profits, governmental organizations, forprofits, and individual community members) collaborate using deliberative democratic practices (Fischer, 2012) to address complex social problems like environmental sustainability and poverty (TD Net, 2009). In this sense, trans-sector TD problem solving transcends the relatively narrow scope of individual societal sectors through the creation of hybrid knowledge systems, synthesizing technical or scientific, political, economic and local knowledge systems, toward the resolution of social problems.

In order to contextualize problems, understand the linkages among problems, and identify leverage points for interventions SEVs are characterized by democratic and participatory modes of collaboration (Nowotny, Scott, \& Gibbons, 2001) to draw on the experience of community members, employees and partners to create "socially robust knowledge" (Klein, 2010) that creates collaborative capacity. Toward that goal, SEVs develop group objectives and shared aims and decision-making power is distributed and not based on capital ownership (Bull, 2008; Dart, 2004). SEVs rely on high quality leaders (Orloff, 2002), who embrace end values such as liberty, social justice, and equality (J. M. Burns, 1978) to foster feelings of community, value-added collaboration, and collective purpose among employees and partners, and mobilize interpersonal and professional networks to create economic and social capital by encouraging citizen engagement and empowering individuals and communities (Bornstein, 2007; Dees, 2001; Martin \& Osberg, 2007; Thompson, 2002; Trivedi \& Stokols, 2011; Waddock \& Post, 1991). From this perspective, SEVs can be conceptualized as exemplar TD systems that are social, collaborative, and collective in their orientation toward addressing complex social problems.

While there is some clarity about the goals and purposes of SEVs and their defining features, very little is understood about the process by which they address societal problems and create sustained positive social change. Many researchers have emphasized the innovativeness of the solution as a key contributing factor (Alvord, Brown, \& Letts, 2004; Ashoka.org; Bornstein, 2007; Dees, 2001; Mair \& Martí, 2006; Schwab Foundation, n.d.; Wei-Skillern, Austin, Leonard, \& Stevenson, 2007). However, in examining how these organizations have overcome struggles and challenges they have faced over time, it becomes obvious that it takes more than just a brilliant idea to create and sustain social change (Bhatt, 2005; Bornstein \& Davis, 2010; Martin \& Osberg, 2015; Trivedi, 2010; Trivedi \& Stokols, 2011). For example, it took the Grameen bank in Bangladesh and Self Employed Women's Association (SEWA) in India (both organizations dedicated to uplifting the social status of women) years before they saw the impacts of their work on women's empowerment (Bhatt, 2005; Hulme, 2008). For example, the Grameen bank provided micro-credit loans to impoverished people who did not have access to the banking system, which enabled them to start small businesses and become part of the financial system. For the first time in the history of the banking industry, banks went door to door to the customers to collect money, demonstrating their flexibility and willingness to change their collection system. They also developed educational programs to promote saving among their customers. Later, they realized the advantages and transformative potential of granting loans to women (over men) and its impact on women's status in their families and society (Rahman, 1999; Yunus \& Jolis, 2007). Their innovative idea was successful because it was supported by the organizational structure. Understanding the process of social change creation and the individual, interpersonal, and 
organizational conditions that facilitate the process is central to design of effective trans-sector TD problem solving ventures.

Prior grounded theory development efforts have focused on the how SEVs conceptualize social problems. This research has revealed that systems thinking and scientific holism in the conceptualization of social problems are critical factors in the creation of social change (Trivedi \& Misra, 2015). These findings are briefly summarized in the following section before moving on to describe the current research, which scrutinizes the role and nature of dialogue and the contextual conditions that support dialogue in the social change process.

\section{TOWARD SOCIAL CHANGE: UNDERSTANDING THE ECOLOGY OF THE SoCIAL PROBLEM}

Since social change is produced by the same factors that produce continuity, one needs to understand the process of social continuity to understand social change creation (Calhoun, 2000). Social continuity is closely linked to prevailing social norms, specifically collective social norms. Social norms are evaluative beliefs that synthesize affective and cognitive elements to orient people to the world in which they live. Social norms are beliefs about the acceptability of behavior. Norms are linked to and reinforced by existential beliefs about human nature, the human condition, and interpersonal relations. Thus, a major cause of resistance to social change is individuals' beliefs in the value of existing social norms (Lewin, 1951). To bring about social change, we need to understand the value individuals place on the norms of the 'collective'. Collective social norms are rooted in the relationship between social action and social structure and can only be understood and influenced by understanding the interconnections between the components of a social system in which social problems are embedded. However, this view has yet to be empirically explored in the context of complex problem solving in social enterprises. Prior research has found that SEVs recognize, expose, and address the underlying structure that leads to patterns of behavior in the system (Trivedi, 2013; Trivedi \& Misra, 2015). Identifying these interconnections requires identifying focal points in the social context where these interconnections occur-an important first step for influencing social norms (Ensminger \& Knight, 1997).

SEVs, as collaborative entities, are unique in the way they frame and approach complex social problems. Social entrepreneurs are especially skilled systems thinkers and understand what we term the ecology of the social problem. The ecology of social problems means the relationship and interaction between a social problem and its context, which includes other social problems (Trivedi \& Misra, 2015). Systems thinking enables them to understand the forces at play in the social system and reveals the underlying structure of the system allowing SEVs to identify leverage points. Social problems are invariably entrenched in the particular social, physical, political, economic, and cultural contexts and are interlinked with other social problems forming an ecosystem. The way in which a society defines their social problems determines the life cycle of the problem, how they are approached, and what is done about them. This is a highly contested process as it deals with divergent and conflicting interests, intentions, and objectives. This interplay of interests influences a society's approach to defining and addressing the social problem (Blumer, 1971).

Effective SEVs conceptualize society as a complex social system in order to develop a holistic understanding of the social problem. According to general systems theory (von Bertalanffy, 1950, 1952), society can be understood as a complex configuration of many systems engaged in overlapping and interlocking patterns of relationships with one another. These subsystems are generally arranged in a hierarchy and work in an integrated fashion to accomplish the goal of the system (Dörner, 1997; Sawyer, 2005). Complex social systems generally have more than one subsystem connected to each other. Each such subsystem has its own boundaries, goals, and input and output processes and continually exchanges feedback with other subsystems. Since each system/subsystem interacts with their environment, they are considered open or dynamic systems. A high functioning system continually 
exchanges feedback among various subsystems to ensure that they are closely aligned to achieve the overall goals of the system. When this is achieved, the system can move from its original state to a more desired state (Dörner, 1997). Conceptualizing social problems in this way allows SEVs to comprehend which entities and stakeholders should be involved while developing a solution to the problem (Trivedi \& Misra, 2015).

Social entrepreneurs often reflect on their own behavior, comment critically on it, and make efforts to modify it (Trivedi, 2013) in an effort to identify imporant stakeholders and gain structural knolwedge about the social system. They conceptualize the ecology of the social problem incrementally through a cyclical thought process of conception, planning, and action. Social entrepreneurs structure their thoughts by asking more 'why' questions than 'what' questions to help them understand the dynamic structure of the social problem (Trivedi, 2013). Jayeshbhai Patel of Manav Sadhna, a social entrepreneurial organization in Ahmedabad, India committed to uplifting underserved children, explains:

I wanted to know why urban slum kids are not interested in education and going to school. So I visited the schools and found that they suffer from an inferiority complex. Whenever they are not able to answer the question asked by the teacher, the teacher would insult them. Eventually they would stop going to school and start working on the street. Working as a child laborer, they have their freedom, have enough money to buy and eat food, and can freely go anywhere they want. They like such freedom. And they also start gaining respect from their parents as they start earning. This simple quest to find the reason made the whole structure of interconnections visible.

Social problems are not isolated entities, but one or more highly organized systems that interact with and depend on each other. These inter-relations are highly abstract and opaque in nature and are controlled by their internal dynamic making them even harder to identify (Dörner, 1997). SEVs that are successful in creating social change are capable of understanding the non-linearity of cause and effect that are or may be distant in time and space (Trivedi \& Misra, 2015). Moreover, there are other intangible and unfamiliar factors such as the social, political, environmental, and cultural context that may alter these systems creating closed loop structures. In such cases, effects feedback to change one or more of the causes and therefore causes affect other causes. In the example of the slum children served by Manav Sadhna, gaining economic freedom and respect from their parents are examples closed-loop structures (effects feedback to one or more causes). Understanding this nonunidirectional relationship between cause and effect, along with how dominance among causes may change over time is vital to understanding the ecology of the social problem and facilitating social change.

Understanding these interactions and interrelations between the subsystems is what Dörner (1997) terms structural knowledge - the knowledge of how the variables in a system are related and how they influence one another. Structural knowledge is essential for complex problem solving (Jonassen, Beissner, \& Yacci, 1993). Comprehending the social system's structure involves (1) organizational knowledge creation and learning that stems from understanding the ecology of social problems and (2) the ability to sense changes in signals from the environment, both internal and external, and adapt accordingly and in a timely manner. Understanding a complex social problem is an iterative process, understood progressively at various levels of analysis (individual, organizational, societal) requiring the coordinated effort of many different actors and integration of activities across functions and knowledge domains. Such ecological knowledge enhances SEVs' ability to recognize and identify the structure of the social problem and structural patterns or archetypes that help them discover constraints and bottlenecks in the system, and devise ways to transform these bottlenecks into leverage points to facilitate social change (Trivedi \& Misra, 2015). The case of SEWA Bank, India, described later in the article, explicates the process of social change creation. 
The research reported here focuses on the role and nature of the communicative process in social change creation in the context of SEVs. Drawing on data from seven SEVs from India and the US and employing a grounded theory methodology, this research scrutinizes the social change process and uncovers the role and characteristics of dialogue in this process. We find that under the appropriate organizational conditions, dialogue is the glue that links together three conditions necessary for social change- conceptualizing the ecology of social problems (structural knowledge creation) (Trivedi \& Misra, 2015), community empowerment, and collaborative capacity (Trivedi, 2013). In understanding the dialogic process and qualities of dialogue, we propose a grounded theoretical conceptual framework linking dialogue to the creation of knowledge networks and collective wisdom, which collectively lead to the creation of positive social change. This framework also elaborates on the organizational conditions that support dialogue in social entrepreneurial organizations as revealed by our research.

\section{RESEARCH METHODOLOGY}

This research draws on a larger research project on how SEVs create sustained social change (Trivedi, 2013). A grounded theory approach was used with theoretical sampling (Glaser \& Strauss, 1967) to understand the local interaction and meanings as related to the social context in which they occur. In grounded theory development, the process of data collection is controlled by the emerging theory. This approach is particularly well suited to studying local interaction and meanings as related to the social context in which they occur. It places more emphasis on participants' own accounts of social and psychological events and their associated local phenomenal and social worlds. Hence, this approach helps in understanding a phenomenon within the socio-political, cultural, economic, spatial, and temporal context in which it occurs (Richardson, 1996). Grounded theory is generated by an iterative process involving continual sampling and analysis of unstructured data collected from interviews, participant observation, and archival research. There are two main components of grounded theory development: (1) constant comparison of the data to the emerging theory and (2) the use of theoretical sampling to build conceptual and theoretical depth of analysis.

“Theoretical sampling” (Glaser \& Strauss, 1967), in which the researcher selects individuals or groups based on the relevance and expected level of novel insights for developing and elaborating the theory, offers an appropriate sampling strategy for this research. In theoretical sampling, groups must be chosen according to well-defined theoretical criteria and decisions about what data to collect next are based on the knowledge drawn from prior material collected. Sampling and integration of material ceases when "theoretical saturation" of a category or group of cases is reached, that is, new insights no longer emerge. Thus, in this method of data collection, coding, and analyses are conducted simultaneously. For example, the objective of this research was to study different types of SEVs that vary in their social missions, developmental trajectories, and socio-political, geographical, and cultural contexts to reveal the full range and variation of SEVs. We, therefore, strove for maximum variation in the sample (Flick, 2002) and included cases that were as different as possible from each other (in terms of their features, processes, and experiences). We selected seven SEVs in India and USA based on their willingness to participate, availability, and potentially novel insights they were able provide to the research.

\section{METHOD}

Qualitative data was collected from seven social entrepreneurial organizations over a period of eight months from July 2011 to February 2012 (see Table 1). This research involved site visits to all seven organizations. Site visits included visits to the headquarters or main office, satellite or field offices, and the actual locations in which the SEVs work such as urban slums, schools, and workshops. Semistructured interviews were conducted with a wide range of members within these social entrepreneurial organizations $(n=27)$, taking care to ensure that they have the necessary knowledge and experience to provide information relevant to the research. Approximately four to five members from each organization participated in this research. These included the social entrepreneurs/founders, 
executive directors, associate directors, coordinators, research coordinators, administrative staff, health administrators, teachers, volunteers, interns, employees, site coordinators, and collaborators/partners. Additional informal interviews were conducted with twenty field workers and volunteers in all of these organizations. All participants in this research have consented to being identified in publications by their real names. Each interview was approximately about 90 minutes long. Data also included informal observations during group meetings and field trips in some of the organizations in a participant-observer role.

Table 1: List of organizations and description of their activities

\begin{tabular}{|c|c|}
\hline ORGANIZATION & DESCRIPTION OF ACTIVITIES \\
\hline $\begin{array}{l}\text { Delancey Street } \\
\text { Foundation, USA }\end{array}$ & $\begin{array}{l}\text { Delancey Street is residential self-help organization for former substance abusers, ex- } \\
\text { convicts, homeless and others who have hit bottom. Delancey Street residents receive a } \\
\text { high school equivalency degree (GED) and are trained in three different marketable } \\
\text { skills. Beyond academic and vocational training, residents learn important values, and } \\
\text { the social and interpersonal skills that enable them to live successfully in the main- } \\
\text { stream of society. }\end{array}$ \\
\hline SAATH, India & $\begin{array}{l}\text { SAATH is a non-governmental organization in Gujarat, India that utilizes market- } \\
\text { based strategies and facilitates participatory processes to create inclusive cities by em- } \\
\text { powering India's urban and rural poor. SAATH's one-stop, integrated services reach } \\
\text { over } 100,000 \text { slum dwellers in Ahmedabad, and many more in Gujarat and Rajasthan } \\
\text { states of India. }\end{array}$ \\
\hline $\begin{array}{l}\text { MAM Movies, } \\
\text { India }\end{array}$ & $\begin{array}{l}\text { MAM Movies is an open source network of voluntary independent filmmakers who } \\
\text { use media, the arts and technology to inform, inspire and empower others to create } \\
\text { positive action in the world. They believe that inner transformation leads to outer } \\
\text { change. The aim is to bring these stories of inner transformation to the general public } \\
\text { through film making and other media (such as blogs). }\end{array}$ \\
\hline Gramshree, India & $\begin{array}{l}\text { The Gramshree Trust was established in } 1995 \text { by Anarben Patel to encourage the em- } \\
\text { powerment of underprivileged women through self-reliant activities. Gramshree pro- } \\
\text { vides women artisans in Gujarat a place where they can leverage their handicraft skills } \\
\text { to save and earn for their families. In } 2002 \text {, Gramshree established a handicraft training } \\
\text { program and a production center. Today Gramshree works with } 750 \text { women in Guja- } \\
\text { rat, providing them with skill training, employment opportunities, and a chance to live } \\
\text { with dignity, financial security and self-reliance. In } 2005 \text {, Gramshree opened a retail } \\
\text { outlet to establish a larger platform from which to market goods produced by women } \\
\text { and artisans. }\end{array}$ \\
\hline $\begin{array}{l}\text { Manav Sadhna, } \\
\text { India }\end{array}$ & $\begin{array}{l}\text { Manav Sadhna, an NGO based at Gandhi Ashram-Ahmedabad works to assist and } \\
\text { uplift poor and needy children. Inspired by Gandhian philosophy, Manav Sadhna } \\
\text { works in the area of education, nutrition, alternatives to child labor and medical aid to } \\
\text { women and children living in the slums. }\end{array}$ \\
\hline $\begin{array}{l}\text { THINK Together, } \\
\text { USA }\end{array}$ & $\begin{array}{l}\text { THINK Together is one of USA's largest and leading non-profit providers of extend- } \\
\text { ed learning time programs (after-school, small group tutoring, summer learning, early } \\
\text { literacy, etc.) in California serving tens of thousands of students at several hundred } \\
\text { sites across the four-county region of Southern California (Los Angeles, Orange, Riv- } \\
\text { erside and San Bernardino Counties). THINK is an acronym that stands for Teaching, } \\
\text { Helping, and Inspiring \& Nurturing Kids. THINK Together's mission is to provide } \\
\text { high-quality, academically oriented out-of-school programs for students regardless of } \\
\text { race, creed, or socioeconomic status. }\end{array}$ \\
\hline
\end{tabular}




\begin{tabular}{|l|l|}
\hline ORGANIZATION & DESCRIPTION OF ACTIVITIES \\
\hline $\begin{array}{l}\text { The Self-Employed } \\
\text { Women's }\end{array}$ & $\begin{array}{l}\text { SEWA is an organization of poor, self-employed women workers with 700,000 mem- } \\
\text { bers who have full employment (mainly through small businesses) and are ensured } \\
\text { (SEWA), India }\end{array}$ \\
$\begin{array}{l}\text { income, food, work, social security, health and child care, old age benefits, as well as } \\
\text { banking and legal services. By providing these employment opportunities, the SEWA } \\
\text { movement has raised the status of women individually and collectively. The SEWA } \\
\text { model has been successfully replicated not only in urban and rural India but also in } \\
\text { other socio-political and cultural contexts such as in South Africa, Turkey, and Yemen. }\end{array}$ \\
\hline
\end{tabular}

\section{Data Analytic Strategies}

Data from the semi-structured interviews and notes from observations were integrated with analyses of archival resources. The archival analysis examined popular media and academic articles about the organization, the organization's website, financial strategy and portfolios, and annual reports pertaining to the organizational structure and goals, financial strategies, as well as the organization's achievements. The documented textual interview data and the archival material were coded, analyzed, and categorized through the "theoretical coding" procedure described by Glaser and Strauss (1967). In the process of interpreting the data and comparing the different cases and processes, coding procedures including "open coding", "axial coding", and "selective coding" were used (Flick, 2002).

"Open coding" aimed to identify themes/categories and associated subcategories emerging from the data (Flick, 2002). The goal therefore was to create multi-dimensional categories from which a preliminary framework for analysis can be generated. Open coding was achieved by analyzing the interview text line by line, by each sentence or by each paragraph. In this research, organic organizational structure and context, ecological understanding of the social problem, and dialogue emerged as the primary categories through which SEVs create and sustain social change. Further sub-categories emerged from the process of "axial coding", in which the goal was to refine and differentiate the categories that emerged from open coding and detect and uncover relationships between the categories and subcategories. For example, within the primary category of dialogue, tacit to explicit knowledge creation, skilled facilitation using metaphorical language, and preserving organizational values through dialogue emerged as secondary categories. Figure 1 (later in this article) shows the relationships between the various categories and sub-categories that emerged in this research.

"Selective coding" is the last step of coding that aimed to identify and elaborate the core rubrics or constructs that were used to group the categories developed earlier through open and axial coding (Flick, 2002). Since the process of gathering and incorporating additional data ended as theoretical saturation was reached, this phase facilitated development of a theory and identified and explained patterns in the data and the conditions under which these applied. For example, one way in which selective coding was used in the present research was to explain the organizational conditions under which large-scale positive social change is created and sustained and the contextual conditions that facilitate and/or constrain the social change creation process, based on the categories, subcategories, and relationships between them found through open and axial coding.

Cross-validation measures such as data triangulation were used to gain a deeper understanding of the organizations and groups participating in this study. For example, in addition to the interviews of the leaders or social entrepreneurs, this research analyzed (1) archival data -- including objective data such as financial portfolios and annual reports of the organization; (2) the mission or vision statement of the organization; (3) past organizational and strategic decisions; and (4) interviews of multiple stakeholders, collaborators, and employees. In this way, theoretical coding and interpretation of the interview and archival data were enriched and corroborated.

We applied Flick's (2014) principle of sequentiality to navigate through the variety of data sources in this research. This means that we followed the data from beginning to end following its temporal development so that the categories emerge, rather than looking for excerpts for substantiating pre- 
conceived categories. Our data analysis therefore aimed to classify and interpret the data to make statements about implicit and explicit dimensions, structures, routines, and practices of meaningmaking in the interview, archival, and observational material. Our final aim was to arrive at generalizable statements by comparing various materials or various texts or several cases. Therefore, the quotes and examples provided below serve as exemplars and are not meant to represent the sole data source that substantiates the emergent categories.

\section{FINDINGS AND EMERGING THEORY}

The reflections and experiences of the members of social entrepreneurial ventures revealed that social entrepreneurship is a collective endeavor and this collective character is essential to its success. Collective organization and synergy, deep intra-organizational communication, and a conducive organizational context are critical for the creation of collective wisdom and knowledge networks for long-term collaborative community capacity building. The theory emerged as the relationships between the concepts combined into an integrated framework that explained the process of social change creation (Strauss \& Corbin, 1990). Dialogue emerged as a central category linking the other themes to explain the process of social change creation. Organic organizational structure enables knowledge creation and integration through the process of organizational learning through deep and continuous social interaction, or dialogue. Illustrative quotations from the participants are included in the each of the categories to tell the story of the theory.

\section{ORGANIC ORGANIZATIONAL STRUCTURE}

An appropriate organizational structure is vital to an organization's success as it provides coordination for organizational processes and facilitates the achievement of collective goals. According to Van de Ven (1986), organizational structural features play an important role in enhancing the morale, efficiency, and effectiveness of the organization. Clemmer (1995) found that organizational structures, if inappropriate, can hinder the performance of motivated employees. Organic organizational structures work well under dynamic conditions and usually have a high level of adaptation. They are most appropriate for an unstable, turbulent, unpredictable environment and for non-routine tasks. SEVs in this research typically employed an organic structure that provided employees with decisional autonomy and control over activities, shifting the primary focus from individual performance to group performance. An organic organizational structure places greater emphasis on social interaction characterized by discussion, elaboration and continuous refinement of tasks and are, therefore, better suited for SEVs (T. A.Burns \& Stalker, 1961; Courtright, Fairhurst, \& Rogers, 1989; Weick, 1987).

Organic structures usually exhibit a low degree of formalization defined as the extent to which policies, procedures, job descriptions, and rules and regulations are codified in writing (Carpenter, Bauer, \& Erdogan, 2010) thus making them amenable to respond quickly and effectively to environmental challenges by enabling employees to exercise a great deal of discretion.

Since the effectiveness of SEVs depends on their ability to acquire accurate structural knowledge, a key requirement for their success would be to foster greater flexibility in acquiring, relating, and interpreting information. Such flexibility requires a low degree of formalization of policies and procedures to allow employees to exercise greater autonomy. Hence, SEVs in this research engaged in what Nonaka (1994) calls "communities of interaction" to facilitate the creation and refinement of structural knowledge. The SEVs that participated in this research exhibited a decentralized structure that supported collective learning. For example, Randy Barth of THINK Together reported:

The culture at THINK Together promotes a collaborative approach that encourages employees to combine their diverse knowledge, talents and expertise in flexible, manageable group-work efforts. This approach aims to foster a supportive structure that facilitates innovation, efficiency and agility to embrace change and keep up with rapid growth. We strive to develop, maintain and reward a culture of trust and 
teamwork. To support this we have a matrix organization structure which seems a natural step to building collaborative organization.

Thus, SEVs put into practice a structure in which authority could be delegated based on structural knowledge to those who are best able to understand and respond to the issue and not based on the employee's position or role in the organization. Jobs are not clearly or precisely defined in such organizations. Positions, roles, job descriptions, and standard operating procedures are broad and generalized rather than specific and specialized (T. A. Burns \& Stalker, 1961). Such an organizational process nurtures the culture of commitment to knowledge creation and sharing among employees. Keren Nazareth at SAATH explained:

We believe in providing lot of autonomy. There is lot of sense of psychological ownership among people working at SAATH. The structure is very organic; that allows us to be flexible and the decision power is distributed. We provide that autonomy to our employees as they are many a times more in tune with the community. We want to understand that and support that. We do question it, but at the end of the day, we give that person a space to make that decision. In our [organizational] history, no person has stepped on anyone's toes when it comes to decision making.

Organic structures foster a consultative communication approach (Courtright et al., 1989) where all knowledgeable contributors participate in decision-making process irrespective of their position within the organization. An organic structure facilitates open communication, empowerment, and delegation of authority creating a path for innovation (Pierce \& Delbecq, 1977; Sine, Mitsuhashi, \& Kirsch, 2006). These types of structures also are well suited to organizations dealing with complex tasks (Hull \& Hage, 1982). It facilitates effectiveness, problem solving, responsiveness, flexibility, adaptability, creativity, and innovation - all critical aspects for complex problem solving (Jonassen et al., 1993; Maani \& Maharaj, 2004; Schein, 1993). Adaptability comes from empowering employees to be creative, to experiment, and to suggest new ideas. Information sharing coupled with decentralized decision-making at all levels of the organization facilitates the generation of fast and suitable responses.

Empowerment of and value-added participation by employees is very motivating because it meets the human need for autonomy, responsibility, challenge, esteem, social interaction, and personal development. This helps SEVs in the development and capitalization of collective intellectual capital generated by employees at various levels of an organization (Helms, 2006). Sunil Vaghela, Health Administrator, at Manav Sadhna explained:

I have complete autonomy to do my work. I am given an annual budget and I have to manage things on my own. If I feel I need to engage in one activity or other at a particular point of time, I have that autonomy and support from the organization and that helps in faster resolutions of problems. And I provide the same kind of autonomy to community leaders that I work with. This also facilitates information flow and helps in identifying emerging issues.

Furthermore, enabling and empowering employees to communicate across traditional organizational boundaries regardless of position, level, or unit through an organic organizational structure improved SEVs' ability to sense and respond to environmental changes. As indicated before, in order to understand and influence structural patterns SEVs must sense changes in signals from the environment, both internal and external, and continually assess and modify their roles, structures, and processes to adapt to environmental needs and respond innovatively to challenges. This requires the coordinated effort of many different actors and integration of activities across functions, knowledge domains, and contexts. It was found that organic organizational structures facilitated this type of knowledge creation, integration, and action. 


\section{ORGANIZATIONAL LEARNING}

Organizational learning is a useful lens to understand cooperative and communicative processes in knowledge creation and integration (Dodgson, 1993). Organizational learning enhances organizations' ability to sense and respond to environmental changes (Flood, 1999). Organizational learning encompasses both processes and outcomes, occurs in all activities of the organization, and is defined as "an organization wide continuous process that enhances its collective ability to accept, make sense of, and respond to internal and external changes" ("Organizational learning", para 1).

Putting the right organizational structure in place is the first step in creating learning organizations. The data in this research uncovered that for SEVs, organizational structures that facilitated social interaction and dialogue were critical for organizational learning and knowledge creation. Solving complex problems requires tapping into the collective intelligence of groups of knowledgeable people. Learning takes place in a social context and it is the nature and boundaries of the context that facilitate the identification of the system constraints or bottlenecks (Easterby-Smith \& Lyles, 2011; Nonaka, 1994; Weick, 1995; Weick, Sutcliffe, \& Obstfeld, 2005). The data revealed that to translate learning into knowledge, the informally shared understanding among various actors needed to be crystallized as a part of a knowledge network (formal and informal knowledge held by the members of organization, within written rules, and in the oral transmission of knowledge through routines and practices). Organizational learning, therefore, is the process of encoding inferences from individual experiences into routines that guide behavior. Thus, organizational learning led to collective knowledge -the accumulated knowledge of the organization stored in its rules, procedures, routines, and shared norms (Levitt \& March, 1988). This systematic integration and collective interpretation of new knowledge led to collective action.

This iterative nature of knowledge creation and integration also indicates a tacit and subjective form of knowledge creation that is deeply rooted in action, commitment, and involvement in the specific context and requires constant, open, and deep interpersonal communication (Weick, 1995). Dialogue, therefore, was found to play a critical role in knowledge creation and facilitate the conversion of tacit knowledge to explicit knowledge. Open communication, delegation of authority, empowerment of employees and stakeholders, and autonomy led to greater flexibility in acquiring, relating, interpreting, and integrating information and locating bottlenecks. Locating bottlenecks enabled SEVs to influence how these bottlenecks work and how they could be maneuvered to meet the organizations' mission. SEVs could therefore capitalize on collective intellectual capital and convert the bottlenecks to leverage points to create social change. For example, the biggest problem that SEWA Bank encountered in its early days was developing a reliable and fair method of accessing the credit worthiness of its clients. These clients were extremely poor, lacked any kind of documentation, and were most likely illiterate. After many encounters with their clients, field employees suggested considering tangible and intangible assets such as ownership of cattle, availability of trade equipment, cash savings, jewelry, basic literacy, or having a husband without a drinking problem, as markers of credit worthiness. This is arguably one of the most innovative features of the SEWA Bank model. This organizational learning could not have emerged without continuous, long-term and deep interpersonal communication across all levels of the organization, and employee autonomy and empowerment.

\section{CONTINUOUS AND DEEP SOCIAL INTERACTION THROUGH DIALOGUE}

Dialogue is the most fundamental of human skills for complex problem solving (Schein, 1993). Rapidly changing external environments create increased need for learning. Learning organizations accept change as an ongoing and dynamic process. Engaging in dialogue, disclosing and testing assumptions, building trust, and generating shared mental models that cut across organizational boundaries are key characteristics that distinguish learning organizations from other types of organizations (Patterson, 2009). Such organizations collect data from their external environment, translate events through deep and open communication, and develop shared understanding and conceptual schema (Daft \& Weick, 
1984). This is done through what Weick et al. (2005) call sensemaking. In the process of sensemaking, events are open to interpretation and many possible meanings can be synthesized. Here strong and supportive leaders clarify values, preferences, and priorities (Patterson, 2009). Thus, leaders are central to the process of creating, sharing, and exploring knowledge at an organizational level (Bryant, 2003). Knowledge creation and organizational learning can be fostered through the appropriate organizational context, as found here, but it also requires strong organizational support and leadership.

\section{Continuous "Samvaad": From Tacit to Explicit Knowledge}

Weick et al. (2005) assert that sensemaking is a social and collective process involving dialogue and communication, a process of collective thinking that relies on mastering the practice of dialogue and discussion that work in a complementary fashion (Senge, Kleiner, Roberts, Ross, \& Smith, 2010).

Dialogue is central to organizational learning because it holds promise as a means for promoting collective thinking and communication (Bohm, 2014; Isaacs, 2001; Senge et al., 2010). Thus, organizational learning starts with dialogue where employees suspend their assumptions and start thinking together (Isaacs, 1993). Jayeshbhai Patel, founder of Manav Sadhna, terms this practice "continuous samvaad" (a Gujarati word that translates to "dialogue" in English). Dialogue, in this context, means a free-flow of meaning through the group, allowing the discovery insights not attainable individually (Senge, 1993).

Among other distinct uses and purposes of a dialogue, Gustavsen (1992) has proposed two that are particularly relevant to SEVs, namely, to defuse conflict and encourage the pooling of ideas or meaning to enable individuals to master complex system realities and become more effective at limiting self-defeating and unintended consequences. Our tacit ways of thinking govern how we formulate our views, deal with differences, pay attention, make causal connections which in turn govern the ways we perceive the world and take action in it (Cowan, David, \& Foray, 2000; Nonaka, 1994; Nonaka \& Von Krogh, 2009). Thus, dialogue is a process in which the group learns to watch or experience its own tacit process in action whereby an attempt is made to bring this tacit infrastructure to the surface, perceive its impact, and alter it (Bohm \& Factor, 1985; Isaacs, 2001). In other words, dialogue provides the platform for the transformation of tacit knowledge into explicit knowledge, which can in turn be converted into organizational routines.

The SEVs in this research provided an environment for individuals to think better collectively, and create and share knowledge. Organizational knowledge creation by SEVs is a process that amplifies the knowledge created by individuals and crystallizes it as a part of the knowledge network of an organization (Dodgson, 1993; Nonaka, 1994). For example, Manav Sadhna promoted organizational learning through the process of dialogue (or samvaad). Every morning, employees came together, sat on the floor in a circle, and started their day with a payer from each major world religion. Such an organization of physical space and organizational routine, provided a sense of equality among employees and facilitates the sharing of experiences and perspectives (Schein, 1993). Then one person from the group read a passage from Gandhi's autobiography, My Experiments with Truth, which was followed by a discussion and elaboration of values underlying the text. This is what Isaacs (2001) refers to as "side by side" interaction, which encourages free exchange between members to enable them to learn to talk together. Jayeshbhai encouraged everyone to share his or her experiences with specific examples. This way, members spoke to the group as a whole rather than speaking directly to one another. Such a process created an environment in which people can express their differences without any effort to reconcile them (Isaacs, 2001). This process invited members to reflect on the quality of language and inquiry they bring to the conversation, and to become self-reflective about how their filters governed their thinking and acting.

It is important not to misunderstand dialogue as any type of verbal communication. Communication can be one-way, but dialogue engages all members in a productive exchange of thoughts and ideas. Isaacs (1993) defines dialogue as, "a sustained collective inquiry into the processes, assumptions, and certainties that compose everyday experience" (p. 25). Hence dialogue, as understood in this context, 
focuses on thinking processes so that an individual becomes more conscious of his/her thought processes enabling him/her to think better collectively. Dialogue, in the SEVs in this research, was found to center on the transformation of the quality of tacit thinking that underlay all interactions (Isaacs, 2001). In these SEVs, engaging in the process of dialogue implied developing a capacity to interact in a way that suspended the habitual processes of thought and meaning that typically controlled members. Reflection coupled with inquiry skills provided the foundation for fruitful dialogue in these organizations as the usage of such skills freed the process of dialogue from particulars of circumstance (Senge et al., 2010), such as the chemistry among team members. Stefano, Gino, Pisano, and Staats (2014) have similarly found that reflection is a powerful mechanism by which experiences are translated into learning. They also found that reflection increases ones' ability to achieve a goal, which in turn translates to higher rate of learning.

\section{Skilled facilitation using metaphorical language}

The data showed that dialogue required a challenging stance of being both an observer and a participant simultaneously requiring the cultivation of reflective awareness and proprioceptive awareness (awareness of what one is doing as one is doing it). With skilled facilitation, this type of stance triggered meaningful dialogue surrounding the organization's work and employees' experiences in the field. Skilled facilitation was found to be critical for the emergence of insights as the facilitator/leader modeled how to suspend habitual thought processes, uncover assumptions, and allow insights to emerge.

Jayeshbhai Patel, founder of Manav Sadhna, enabled members to articulate their perspectives by the use of metaphorical language to express the meaning and feelings involved in the learning process, thereby revealing hidden and tacit knowledge that is otherwise difficult to communicate. For instance, on the topic of mentorship he explained:

Leaders have to balance between molding the employee's values toward right direction as well as supporting them at each step to realize those values. It is like the work of a potter, who uses his upper hand to shape the clay to turn in to a beautiful earthen pot, while always supporting that action by other, invisible, hand from inside so that the created form retains its shape and does not break.

On the idea of leadership, Jayeshbhai said:

One should not strive to be a "yogi" (preacher), but instead try to be "upyogi" (helpful). There is no place for assumption or judgement. There is only equality or viewing each other with equanimity (Samdhristi). When you change your perspective, we change the world around us. I am not here to preach or teach anyone. I am here to share my thoughts. A leader is the one who centralizes, while a ladder is the one who decentralizes. In centralization your "I" [ego] becomes capital, in decentralization it becomes small "i". In decentralization, you have sharing, you have caring. This can become a movement, a mission. While centralization often evolves ambition. One should try to be a ladder for other to achieve their success, rather than becoming a leader."

Further, on the idea of success Madhusudan of MAM Movies explained in one of the group sessions:

Success is form of external validation. Once you start following your swagyan (selfunderstanding), you do not require external validation and it does not matter whether you help one person or ten or one hundred in a day. This enlightenment makes you very fearless of success and failure. And second, it helps you to understand that you are just an instrument and that helps you with the understanding that MAM (organization) is just a vehicle and you can do work with or without it. 
And Mimi Silbert of Delancey Street Foundation, wrote on the idea of continuing in the face of difficulties,

I'm like a mother figure. I love them. They love me and we're climbing a mountain together. I tell them, "I might be closer to the top of the mountain, and you might feel closer to the bottom but the truth is; the people at the bottom hold the power. If you pull in a negative direction, we'll all fall down the mountain - and Delancey Street will be over. If you pull each other up, we'll all make it up. And the pie is big enough for all of us, so here we go.” (McCoy, 2014)

Social interaction is the key and is accomplished through communal living and with open interactions with various elements of community. The stress is on fun, humor, and interpersonal communication skills (Silbert, 1984).

The usage of metaphors is an effective method of converting tacit knowledge to explicit knowledge (Nonaka, 1994). "The essence of metaphor is understanding and experiencing one kind of thing in terms of another" (Lakoff \& Johnson, 1980, p. 5). Metaphors enable individuals to experience new behaviors by making inferences from models of other behaviors. While perception through prototype is in many cases limited to concrete, mundane concepts, metaphor plays an important role in associating abstract, imaginary concepts. When two concepts are presented in a metaphor, it is possible not only to think of their similarity, but also to make comparisons that discern the degree of imbalance, contradiction or inconsistency involved in their association.

Metaphors enable the finding of fresh ways of seeing, understanding and shaping the situation we want to organize and manage (Morgan, 2006). The latter process becomes the basis for creating new meaning. Some metaphors provide familiar ways of thinking while others develop new insights and perspectives. Overall, metaphors can generate a range of complementary and competing insights and help to build on the strengths of different perspectives. Additionally, metaphors serve as a way of creating a network of concepts that can help generate future knowledge using existing information.

Hence, the process of dialogue is a creative, cognitive process that relates seemingly disparate concepts within an individual's cognitive schema. Dialogue thus becomes a vehicle for thinking genera-

tively, creatively, and importantly thinking together. It facilitates the natural flow of conversations and allows members to be self-reflective.

This continuous interplay of enhancing the creation of tacit knowledge through self-reflection with relevant aspects of explicit knowledge improves the total quality of the individual's structural knowledge (Nonaka, 1994). At MAM Movies, for example, the regular sharing of experiences enabled this. Sharing experiences through dialogue facilitated the creation of common perspectives and helped establish a common basis for understanding each other and the organization's goals and objectives. Thus, social interaction through dialogue created shared understanding and common interpretive schemas that could then facilitate organizational learning.

\section{Activating organizational values using dialogue}

This research found that dialogue served the purpose of preserving the organizational values and keeping them cognitively active as exemplified by Jayeshbhai Patel's role in tying organizational learning to organizational values at the end of each such session of "samvaad" or dialogue. For example, Manav Sadhna displayed its values all across the organization -- "Happiness depends on what you can give and not what you can get"; "Service to mankind"; "Home for the underprivileged", "Be the change you want to see in this world."

Verplanken and Holland (2002) have found that individuals make choices consistent with their values when those values are cognitively activated. Thus, the knowledge generated along with cognitively active organizational values facilitates behavior and processes that crystallize the new knowledge into behavior and routines. Such a learning process creates strong organizational culture that encourages normative behavior (Schein, 1993). Organizational culture is defined here as (a) a pattern of basic 
assumptions, (b) invented, discovered, or developed by a given group, (c) as it learns to cope with its problems of external adaptation and internal integration, (d) that has worked well enough to be considered valid and, therefore (e) is to be taught to new members as the (f) correct way to perceive, think, and feel in relation to those problems (Schein, 1990). Values have been found to influence habitual behavior through affective mechanisms (Bardi \& Schwartz, 2003). Social interaction, therefore, has the capacity to generate synergy. That is, the added value results not from the cumulative effects of elements present in the milieu but from the interaction. Thus, the practice of dialogue helps SEVs strengthen organizational learning and better realize their organizational values.

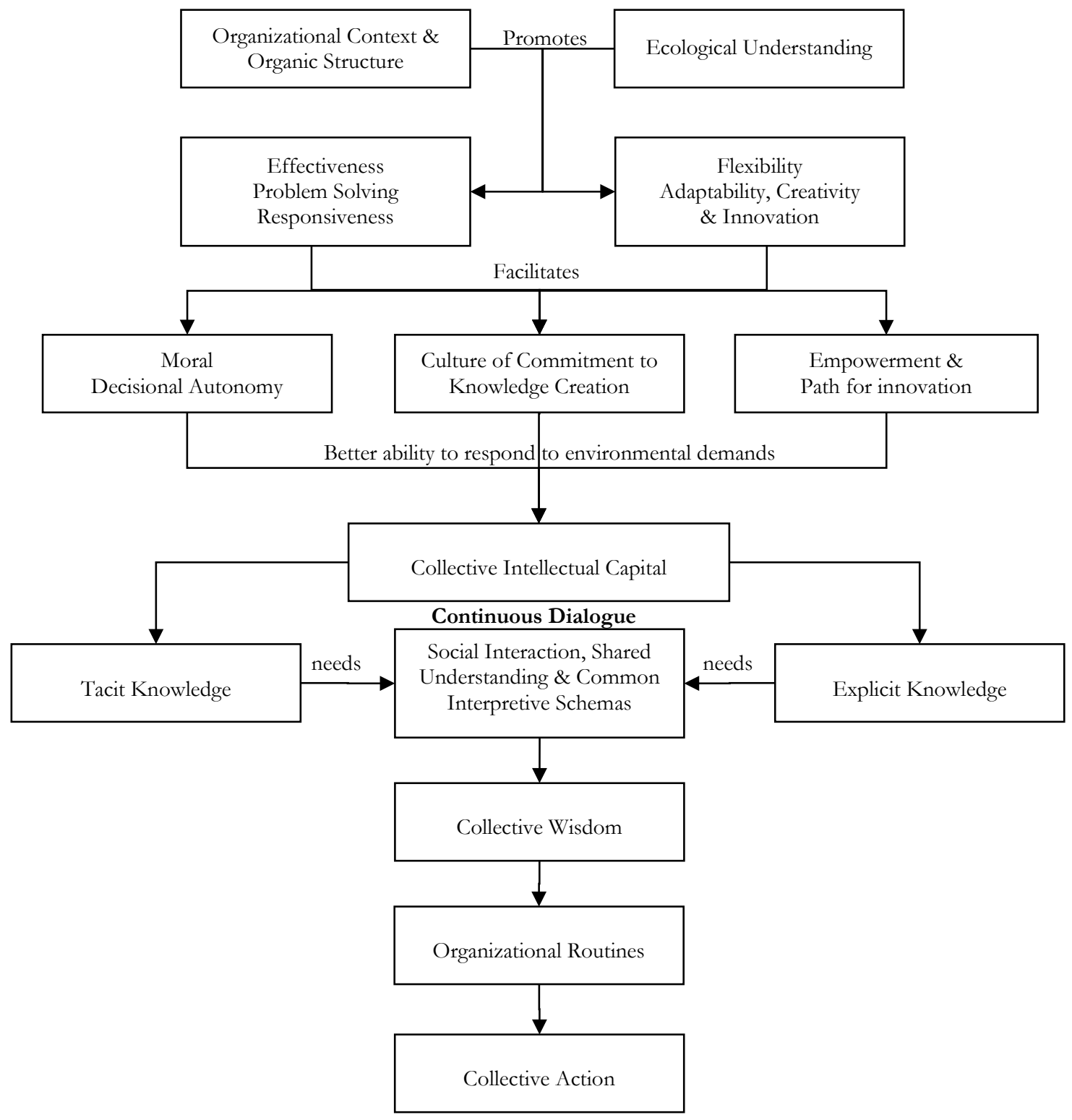

Figure 1: Knowledge Creation and Organizational Learning through Dialogue

The core of the grounded theory of dialogue in the context of trans-sector TD problem solving organizations presented here is built on the premise that the effect of people's shared attention can alter the quality and level of inquiry possible at any particular time. People can gradually learn to refine their modes of collective awareness to promote increasingly more subtle and intelligent modes of interaction. The process is very demanding, and at times frustrating; it is also deeply rewarding. 
Figure 1 depicts graphically the relationships between the constructs that emerged from the data and centrality of dialogue in the process of knowledge creation, organizational learning, and collective action.

Below, we use the case of Self-Employed Women's Association (SEWA) Bank to clarify the linkages between these concepts and explain how they are critical to the creation and sustenance of positive social change.

\section{The Process of Social Change: The Case of SEWA Bank}

SEWA Bank was started against all odds - the clients were illiterate, there was no system to evaluate the credit worthiness of clients, and the savings deposited were marginal. And yet, SEWA bank shattered the myth that the poor are not bankable and turned their bank into a viable, profitable, financial venture without any aid or subsidy year after year since its inception in early 1970s by devising new and innovative solutions to all these problems (Bhatt, 2005).

\section{COMPLEXITY OF THE SOCIAL PROBLEM}

The informal or unorganized sector constitutes about $50 \%$ of the GDP of India and provides livelihood to almost $90 \%$ of the work force (Government of India, 2012; Kabra, 2003; Sakthivel \& Joddar, 2006). The unorganized sector in India consists of people who earn their living through their own small business or by selling their own labor. Despite their hard work and significant contribution to the national economy, they do not have access to financial services (Bhatt, 2005). Hence, they face two major challenges - lack of working capital and non-ownership of assets. As a result, a big portion of their little income goes toward interest on working capital and renting trade equipment. Paying high interest leads to the lack of business infrastructure, which in turn leads to the lack of capital, savings, and assets. The Government of India has attempted, in the form of various financial schemes implemented by nationalized banks, to help the unorganized sector gain access to financial services (Bhatt, 2005). However, these have not been effective in uplifting the self-employed poor in the informal sector, largely owing to the structure of banking in India. For example, most workers in the unorganized sector live hand to mouth, which is very labor intensive. They have no time bring their earnings to the bank during regular bank hours. Also, they need to make frequent deposits in order to be able to save or else they spend everything they earn. Furthermore, it is uneconomical for them to spend money on transportation to the bank for small amounts of money that have to be deposited frequently. Even for those who are a little better off economically, in order to get a loan they need collateral deposits and a strong credit history. They need to be literate to be able to open a bank account, to be able to fill out the forms, and they need some type of asset to qualify for a loan. Thus, these structural conditions limit the benefits of government initiated financial schemes for participants in the informal sector. The system boundaries are so rigidly defined that the entities involved are not able to understand each other's needs. Banks implementing such financial schemes to help the poor do not understand their clients and do not have adequate means to measure the credit worthiness of self-employed people. The poor feel intimidated by the formal office and banking environments, where they would have to deposit a crumbled pile of currency in small denomination. At the same time, bankers have a distrust of the poor and are condescending toward them and their economic activities.

\section{INNOVATIVENESS OF SE VS: ORGANIZATIONAL CONTEXT, ORGANIC STRUCTURE, ECOLOGY OF THE SOCIAL PROBLEM}

SEWA established their own bank (SEWA Bank) in 1974. It was based on the cooperative model where members were also the shareholders of the bank. To remain true to their cooperative model, not only are the banking services for poor women, the management is also comprised of poor women (Bhatt, 2005). Thus, there was a strong alignment of interests and objectives between the board, the management, and the customers. The women who constituted the bank were the women for 
whom the bank was constituted. Therefore, the bank was able to comprehend their customers' needs as it was the same critical mass of women who demanded and provided the services. SEWA bank employed unconventional systems thinking principles to build a banking system for their clientele. Perseverance, egalitarianism, inclusion, and participation are actively incorporated into meetings and organizational practices (Blaxall, 2004). The organizational structure encouraged experimentation and learning and willingness to take advantage of the partnership.

To tackle the challenge of illiteracy, SEWA Bank started providing photo identity cards for account holders and supplemented it with a dedicated person in the bank to help anyone with the forms and other paperwork. SEWA Bank devised a door-to-door service and a daily collection schedule to facilitate and cultivate the habit of saving. Such a flexible system, coupled with decentralized decisionmaking power, promoted motivation and commitment in employees. This made the system boundaries porous and gave them the ability to understand their customers' needs. Empowered employees developed their own system of assessing credit worthiness of their customers. For example, availability of trade equipment, cash, savings, jewelry, a roof over their head, real estate, owning a cow or other animals, food ration card, or having any certificate or license, are considered valuable assets by SEWA Bank. SEWA bank also takes into account intangible assets such as education, basic literacy, number of children, a husband without a drinking problem, in-laws who are liberal and allow a woman to work outside the house, when assessing the credit worthiness of a client. It took a combination of unconventional thinking and a constant reevaluation of clients' needs through continuous dialogue to identify assets that clients can turn into capital and build and sustain successful banking model for the poor (Bhatt, 2005).

Further, bank frontline workers, known as 'bank-saathis', who typically belong to the same community and live in the same neighborhood as customers, help identify these assets, and help with the daily collection of savings. They also assist with loan application assessments. They have considerable autonomy in assessing the customers' credit worthiness. SEWA bank, like other SEVs in this study, has an organic organizational structure whereby decision-making power is based on knowledge rather than position. Such practices allow the creation of new knowledge, which is then crystallized into predictable organizational routines. The leadership at SEWA bank facilitated the establishment of participatory management and behavioral practices to reduce the social distance between the management and the community members. This included regular rotation of office holders, highly compressed pay scales, a stable core management cadre, and a conscious policy of developing new leaders (Blaxall, 2004). SEWA bank understood that in order to serve their customers effectively, they need to understand their work and their requirements. Through bank-saathis, SEWA bank refined its structural knowledge and understanding of interconnections among different social variables, which was then codified into organizational routines.

At the same time, SEWA Bank understands the ecology of the social problem and provides other supportive services such as, advice on how to cook and feed a family with limited resources and where and how to spend money. It also provides assistance in finding the best and most affordable deals for purchasing trade equipment, so that customers can start exercising financial discipline. The bank also identifies potential areas where it can provide supplementary help such as legal services, medical services, insurance, capacity building, and marketing knowhow to its clients. For the extreme poor, whose credit worthiness is impossible to assess, or where the identity of a person cannot be verified, the Bank helps them in procuring a ration card, a voting card, or an electricity connection. In addition, to equip women in making sound financial choices, the bank conducts training programs, where women can learn about financial planning. The Bank also places great importance on the redemption of old debts with moneylenders, pawnshops, or property owners as it frees women from life-long indebtedness and helps to increase their bargaining power with wholesalers and suppliers. 


\section{CRYSTALLIZATION OF SOCIAL CHANGE}

Once a saving pattern is established, things start turning around. Women feel more self-confident once they realize they have money accumulating in their account. Bhatt (2005) notes that when financial tensions ease for women, their husband's attitude softens and they start considering women as partners rather than a burden. Gradually, women begin to have a voice in the family, and family-byfamily and neighborhood-by-neighborhood; social change starts to gain momentum. Wilson (1996) argues that individual change is a prerequisite for community and social change. Page and Czuba (1999) refer to this phenomenon as empowerment, which is a "multi-dimensional social process that helps people gain control over their own lives" (para 11).

Over years, the bond between SEWA Bank and the women they serve became stronger and most women developed a strong support structure to help them realize their dreams. This process of raising the status of women individually and collectively is a long-term process that involves hard work by many. Continuous social support leads to greater awareness of new opportunities. This is a subconscious process whereby society gradually progresses as knowledge of new forms of social institutions spreads over time (Jacobs \& Asokan, 1999). Social entrepreneurs play a key role in making this knowledge broadly available. Though social entrepreneurs or leaders appear to act individually, they are conscious and enlightened representatives of the society and hence their role should be viewed in that light (Cleveland \& Jacobs, 1999). The success of SEVs encourages subsequent imitation and propagation in their immediate communities and beyond. Growing success leads to the assimilation of the new practices in the society and over the course of time these practices become regularized and institutionalized.

\section{CONCLUSION}

This research employs a social ecological perspective (Stokols, 2018) to develop a grounded theory of knowledge creation and organizational learning in trans-sector TD problem solving contexts, such as social entrepreneurial ventures. Three salient conclusions emerge from this study of the social change process in seven SEVs in India and the US.

(1) Dialogue and its ability to generate knowledge networks and collective wisdom play a vital role in the complex problem solving and social change process. We developed a grounded theoretical framework elucidating the role of dialogue in the process of social change creation and sustenance with particular attention to the organizational conditions and context.

(2) This research highlighted how the appropriate organizational context can support dialogue, promote the generation of individual and organizational learning, amplify the knowledge created by individuals, and allow the crystallization of knowledge as a part of the knowledge network of the organization, which in turn leads to collective wisdom and action. Key elements of such an organizational context include (a) understanding the ecology of the social problem; (b) organic organizational structure; (c) continuous and deep social interaction among all levels of the organization through dialogue; (d) employee and community autonomy and empowerment, and (e) attention to subtle environmental changes in the system. These elements in combination lead to the creation of collective wisdom. Collective wisdom then feeds back into the conception, planning, and action stages of the iterative cycle of organizational knowledge creation to create positive social change. Figure 1 maps the relationship between the various categories and sub-categories that emerged from the data.

(3) At the same time, this research identified the nature and characteristics of the dialogic process that lead to the generation of organizational learning and collective wisdom - continuous samvaad (open and deep communication), skilled facilitation using metaphorical language, and cognitive activation of organizational values to promote organizational norms.

In summary, we found that in order to create and sustain positive social change, SEVs first understand the interconnections between the components of the social structure that produce and main- 
tain social continuity and collective social norms. This ecological understanding of the dynamic nature of the structure of the social problem is gained through a process of questioning and probing, experimentation, evaluation, and learning. Gaining knowledge of the ecology of the social problem is an iterative process, understood progressively at various levels of analysis (individual, organizational, societal) and requires the coordinated effort of many different actors and the integration of activities across functions and knowledge domains. It was found that multiple actors at different levels of the organization are engaged in a continuous and iterative cycle of conception, planning, and action.

Each action, in turn, produces both intended and unintended consequences. Through consolidation and accumulation, these consequences result in the creation and refinement of structural knowledge. Structural knowledge can be tacit or explicit. Tacit and subjective forms of knowledge creation need constant, open, and deep interpersonal communication to convert them into explicit knowledge. This transformation was found to be facilitated by dialogue. Dialogue aided the creation of shared understanding and common interpretive schemas, while empowering the community and building collaborative community capacity, and led to the creation of collective wisdom. This wisdom fuels the next round of conception, planning, and action as structural knowledge is further refined through this iterative process of gaining ecological understanding.

In addition to ecological understanding, the ability to sense internal and external environmental changes is required for the organization to adapt to these changes. This in turn depends on actors' (employees, community, and other stakeholders) ability to acquire, relate, and interpret information. Organizational structures that promote empowerment and autonomy are better suited to promote ecological understanding of the social problem, sense external changes, and create structural knowledge. Such an organizational context fosters effective problem solving, flexibility, adaptability, creativity, and innovation.

The research methodology employed in this study is progressive and discovery based. It is interpretative, emphasizes thick description of multiple cases, and is contextually sensitive. It emphasizes the meaning of experiences and behavior in context and its full complexity. The method provides a richer and deeper understanding of trans-sector TD problem solving using the case of social entrepreneurship and social entrepreneurial ventures compared to a quantitative approach that can provide greater generalizability. However, this approach also has number of limitations. For instance, the range and number of SEVs that can be studied is limited. It was not possible to study a broader range of SEVs that likely would have yielded additional insights, due to geographical, language, economic, time, and other constraints. Further, there are some limitations inherent to qualitative methodology. For example, since only a small group of cases or organizations are studied, the results might not be generalizable to all contexts and populations. Additionally, it may be difficult to disentangle interviewee biases in interview data. However, the research presented here did not rely solely on interview data. Cross-validation strategies such as data triangulation were used to gain a deeper understanding of the organizations and groups involved and avoid interviewee biases.

Limitations notwithstanding, several novel lines of research can be pursued based on the findings of this research. For example, this research provides a foundation for modeling theoretically and studying empirically the ecology of social entrepreneurship and trans-sector TD problem solving more broadly-- especially the ways in which the personal attributes of social entrepreneurs (e.g., their leadership style, networking abilities) combine with circumstances at organizational, institutional, and international levels to influence the effectiveness of their efforts to promote positive social change within local and global communities. Second, the grounded theoretical framework developed here should be further refined and elaborated through the identification of additional key contextual factors that affect SEVs' capacity to promote positive social change and to achieve sustainability in different socio-environmental contexts. That is, we need to dig deeper into the processes by which the innovations created by SEVs are diffused into societal as a whole, thereby influencing the actions of other entities such as governmental, corporate, and non-profit organizations. We also need a better 
understanding how we can replicate the efforts of SEVs when the social problem and its effects are not immediately apparent or visible — as in the case of global climate change.

Finally, while our findings shed light on the key elements and processes that social enterprises employ in their efforts to create positive social change and alleviate some of the most complex and longstanding social problems of our time, much remains to be done. Future research needs to translate these ideas in ways that discursively promote integration of knowledge relevant to the social problem, creation of more inclusive problem solving contexts and practices, and mutual understanding and deliberation among participants of trans-sector TD problem solving contexts.

\section{REFERENCES}

Alvord, S. H., Brown, L. D., \& Letts, C. W. (2004). Social entrepreneurship \& societal transformation: An exploratory study. Journal of Applied Behavioral Science, 40(3), 260-282. https://doi.org/10.1177/0021886304266847

Ashoka. (n.d.) Ashoka: Innovators for the public. Retrieved from http://www.ashoka.org/support/criteria

Austin, J. E. (2000). The collaboration challenge: How nonprofits and businesses succeed through strategic alliances (1st ed.). San Francisco, Calif.: Jossey-Bass Publishers.

Bardi, A., \& Schwartz, S. H. (2003). Values and behavior: Strength and structure of relations. Personality and Social Psychology Bulletin, 29(10), 1207-1220. https://doi.org/10.1177/0146167203254602

Barringer, B. R., \& Harrison, J. S. (2000). Walking a tightrope: Creating value through interorganizational relationships. Journal of Management, 26(3), 367-403. https://doi.org/10.1177/014920630002600302

Bhatt, E. R. (2005). We are poor but so many: The story of self-employed women in India. New Delhi: Oxford University Press.

Blaxall, J. (2004, May 25-27). India's Self-Employed Women's Association (SEWA): Empowerment through mobilization of poor women on a large scale. Paper presented at the Scaling Up Poverty Reduction: A Global Learning Process and Conference, Shanghai.

Blumer, H. (1971). Social problems as collective behavior. Social Problems, 18(3), 298-306. https://doi.org/10.2307/799797

Bohm, D. (2014). On dialogue. London: Routledge.

Bohm, D., \& Factor, D. (1985). Unfolding meaning: A weekend of dialogue with David Bohm. NewYork, NY: Routledge.

Bornstein, D. (2007). How to change the world: Social entrepreneurs and the power of new ideas (updated ed.). NY: Oxford University Press Inc.

Bornstein, D., \& Davis, S. (2010). Social entrepreneurship: What everyone needs to know. New York, NY: Oxford University Press, USA.

Bovaird, T. (2004). Public-private partnerships: From contested concepts to prevalent practice. International Review of Administrative Sciences, 70(2), 199-215. https://doi.org/10.1177/0020852304044250

Bryant, S. E. (2003). The role of transformational and transactional leadership in creating, sharing and exploiting organizational knowledge. Journal of Leadership \& Organizational Studies, 9(4), 32-44. https://doi.org/10.1177/107179190300900403

Bull, M. (2008). Challenging tensions: Critical, theoretical and empirical perspectives on social enterprise. International Journal of Entrepreneurial Behaviour \& Research, 14(5), 268-275. https://doi.org/10.1108/13552550810897641

Burns, J. M. (1978). Leadership. New York, NY: Harper \& Row.

Burns, T. A., \& Stalker, G. M. (1961). The management of innovation. London: Tavistock Publications.

Calhoun, C. (2000). Social change. In E. F. Borgatta \& R. J. V. Montgomery (Eds.), Encyclopedia of sociology (2nd ed., Vol. 4, pp. 2641-2648). New York: Macmillan Reference. 
Dialogue and the Creation of Transformative Social Change

Carpenter, M., Bauer, T., \& Erdogan, B. (2010). Principles of management. Irvington, NY: Flatworld Knowledge.

Child, J., \& Faulkner, D. (1998). Strategies of cooperation: Managing alliances, networks and joint ventures. London: Oxford University Press.

Clemmer, J. (1995). Pathways to performance: A guide to transforming yourself, your team, and your organization. Toronto, Canada: Clemmer Group.

Cleveland, H., \& Jacobs, G. (1999). The genetic code for social development. In H. Cleveland, G. Jacobs, R. Macfarlane, R. v. Harten, \& N. Asokan (Eds.), Human choice: The genetic code for social development (p. 7). Minneapolis, MN: World Academy of Art and Science.

Courtright, J. A., Fairhurst, G. T., \& Rogers, L. E. (1989). Interaction patterns in organic and mechanistic systems. The Academy of Management Journal, 32(4), 773-802. https://doi.org/10.2307/256568

Cowan, R., David, P. A., \& Foray, D. (2000). The explicit economics of knowledge codification and tacitness. Industrial and Corporate Change, 9(2), 211-253. https://doi.org/10.1093/icc/9.2.211

Daft, R. L., \& Weick, K. E. (1984). Toward a model of organizations as interpretation systems. The Academy of Management Review, 9(2), 284-295. https://doi.org/10.2307/258441

Dart, R. (2004). The legitimacy of social enterprise. Nonprofit Management and Leadership, 14(4), 411-424. https://doi.org/10.1002/nml.43

Dees, J. G. (2001). The meaning of "Social Entrepreneurship”. Retrieved from https://entrepreneurship.duke.edu/news-item/the-meaning-of-social-entrepreneurship/

Dodgson, M. (1993). Organizational learning: A review of some literatures. Organization Studies, 14(3), 375-394. https://doi.org/10.1177/017084069301400303

Dörner, D. (1997). The logic of failure: Recognizing and avoiding error in complex situations: Basic Books.

Easterby-Smith, M., \& Lyles, M. A. (2011). Handbook of organizational learning and knowledge management (2nd ed.). Chichester, West Sussex: Wiley.

Ensminger, J., \& Knight, J. (1997). Changing social norms: Common property, bridewealth, and clan exogamy. Current Anthropology, 38(1), 1-24. https://doi.org/10.1086/204579

Fischer, F. (2012). Participatory governance: From theory to practice. In D. Levi-Faur (Ed.), The Oxford handbook of governance (pp. 457-471). Oxford, New York: Oxford University Press. https://doi.org/10.1093/oxfordhb/9780199560530.013.0032

Flick, U. (2002). An introduction to qualitative research (2nd ed.). Thousand Oaks, CA: Sage Publications.

Flick, U. (Ed.). (2014). The Sage bandbook of qualitative data analysis. London, UK: Sage. https://doi.org/10.4135/9781446282243

Flood, R. L. (1999). Retbinking the fifth discipline: Learning within the unknowable. London: Routledge.

Galatsidas, A., \& Sheehy, F. (2015, July 6). What have the millennium development goals achieved? The Guardian. Retrieved from https://www.theguardian.com/global-development/datablog/2015/jul/06/whatmillennium-development-goals-achieved-mdgs

Glaser, B. G., \& Strauss, A. L. (1967). The discovery of grounded theory: Strategies for qualitative research. Chicago: Aldine Publishing Company.

Government of India. (2012). Report of the committee on unorganised sector statistics. Retrieved from http://www.lmis.gov.in/sites/default/files/NSC-report-unorg-sector-statistics.pdf

Gustavsen, B. (1992). Dialogue and development: Theory of communication, action research and the restructuring of working life. Assen, Netherlands: Van Gorcum.

Helms, M. M. (2006). Organic organizations. In M. M. Helms (Ed.), Encyclopedia of Management (5th ed., Vol. 1): Gale Cengage.

Hull, F., \& Hage, J. (1982). Organizing for innovation: Beyond Burns and Stalker's organic type. Sociology, 16(4), 564-577. https://doi.org/10.1177/0038038582016004006 
Hulme, D. (2008). The story of the Grameen Bank: From subsidised microcredit to market-based microfinance. Brooks World Poverty Institute Working Paper (60). https://doi.org/10.2139/ssrn.1300930

Isaacs, W. N. (1993). Taking flight: Dialogue, collective thinking, and organizational learning. Organizational Dynamics, 22(2), 24-39. https://doi.org/10.1016/0090-2616(93)90051-2

Isaacs, W. N. (2001). Toward an action theory of dialogue. International Journal of Public Administration, 24(7-8), 709-748. https://doi.org/10.1081/PAD-100104771

Jacobs, G., \& Asokan, N. (1999). Towards a comprehensive theory of social development. In H. Cleveland, G. Jacobs, R. Macfarlane, R. v. Harten, \& N. Asokan (Eds.), Human choice: The genetic code for social development (pp. 152). Minneapolis, MN: World Academy of Art and Science.

Jonassen, D. H., Beissner, K., \& Yacci, M. (1993). Structural knowledge: Techniques for representing, conveying, and acquiring structural knowledge. Hillsdale, New Jersey: Lawrence Erlbaum.

Kabra, K. N. (2003). The unorganised sector in India: Some issues bearing on the search for alternatives. Social Scientist, 31(11/12), 23-46. https://doi.org/10.2307/3517948

Klein, J. T. (2010). A taxonomy of interdisciplinarity. In R. Frodeman, J. T. Kelin, \& C. Mitcham (Eds.), The Oxford handbook of interdisciplinarity. Oxford, UK: Oxford University Press.

Lakoff, G., \& Johnson, M. (1980). Metaphors we live by. Chicago, IL: University of Chicago Press.

Levitt, B., \& March, J. G. (1988). Organizational learning. Annual Review of Sociology, 14, 319-340. https://doi.org/10.1146/annurev.so.14.080188.001535

Lewin, K. (1951). Field theory in social science. New York: Harper.

Maani, K. E., \& Maharaj, V. (2004). Links between systems thinking and complex decision making. System Dynamics Review, 20(1), 21-48. https://doi.org/10.1002/sdr.281

Mair, J., \& Martí, I. (2006). Social entrepreneurship research: A source of explanation, prediction, and delight. Journal of World Business, 41(1), 36-44. https://doi.org/10.1016/j.jwb.2005.09.002

Martin, R. L., \& Osberg, S. R. (2007). Social entrepreneurship: The case for definition. Stanford Social Innovation Review, Spring, 29-39.

Martin, R. L., \& Osberg, S. R. (2015). Getting beyond better: How social entrepreneurship works. Boston, MA: Harvard Business Review Press.

McCoy, D. L. (2014). Remarkable leaders: Risk takers who dare us! American Spirit Foundation.

Morgan, G. (2006). Images of organization (Updated ed.). Thousand Oaks: Sage Publications.

Nonaka, I. (1994). A dynamic theory of organizational knowledge creation. Organization Science, 5(1), 14-37. https://doi.org/10.1287/orsc.5.1.14

Nonaka, I., \& Von Krogh, G. (2009). Perspective—tacit knowledge and knowledge conversion: Controversy and advancement in organizational knowledge creation theory. Organization science, 20(3), 635-652. https://doi.org/10.1287/orsc.1080.0412

Nowotny, H., Scott, P. B., \& Gibbons, M. T. (2001). Re-tbinking science: Knowledge and the public in an age of uncertainty Cambridge: U: Polity Press.

Organizational learning. (n.d.), In BusinessDictionary.com. Retrieved from http://www.businessdictionary.com/definition/organizational-learning.html

Orloff, A. (2002). Social venture partners calgary: Emergence and early stages: A case study. Canadian Centre for Social Entrepreneurship. Retrieved from http://www.business.ualberta.ca/ccse/publications/publications/SVPCalgary\%20CAse\%20Study.pdf

Page, N., \& Czuba, C. E. (1999). Empowerment: What is it? Journal of Extension, 37(5), 1-5.

Patterson, J. A. (2009). Organisational learning and leadership: On metaphor, meaning making, liminality and intercultural communication. International Journal of Learning and Change, 3(4), 382-393. https://doi.org/10.1504/IJLC.2009.026220 
Dialogue and the Creation of Transformative Social Change

Peredo, A. M., \& Chrisman, J. J. (2006). Toward a theory of community based enterprise. Academy of Management Review, 31 309-328.

Pierce, J. L., \& Delbecq, A. L. (1977). Organization structure, individual attitudes and innovation. Academy of Management Review, 2(1), 27-37. https://doi.org/10.5465/AMR.2006.20208683

Rahman, A. (1999). Women and microcredit in rural Bangladesh: Anthropological study of the rhetoric and realities of Grameen bank lending. Boulder, Colo.: Westview Press.

Richardson, J. T. E. (Ed.) (1996). Handbook of qualitative research methods for psychology and the social sciences. Malden, MA: Blackwell Publishers.

Sakthivel, S., \& Joddar, P. (2006). Unorganised sector workforce in India: Trends, patterns and social security coverage. Economic and Political Weekly, 2107-2114.

Sawyer, R. K. (2005). Social emergence: Societies as complex systems: Cambridge University Press. https://doi.org/10.1017/CBO9780511734892

Schein, E. H. (1990). Organizational culture. American Psychologist, 45(2), 109-119. http://doi.org/10.1037/0003$\underline{066 X .45 .2 .109}$

Schein, E. H. (1993). On dialogue, culture, and organizational learning. Organizational Dynamics, 22(2), 40-51. https://doi.org/10.1016/0090-2616(93)90052-3

Schwab Foundation. (n.d.). Schwab Foundation for Social Entrepreneurship. Retrieved from http://www.schwabfound.org/sf/index.htm

Senge, P. M. (1993). The fifth discipline: The art \& practice of the learning organization. New York, NY: Currency Doubleday.

Senge, P. M., Kleiner, A., Roberts, C., Ross, R. B., \& Smith, B. J. (2010). The fifth discipline fieldbook: Strategies and tools for building a learning organization. New York: Nicholas Brealey Publishing.

Silbert, M. (1984). Delancey Street Foundation: A process of mutual restitution. In F. Reissman \& A. Garrtner (Eds.), Self-help revolution. New York: Human Sciences Press Inc.

Sine, W. D., Mitsuhashi, H., \& Kirsch, D. A. (2006). Revisiting Burns and Stalker: Formal structure and new venture performance in emerging economic sectors. The Academy of Management Journal, 49(1), 121-132. https://doi.org/10.5465/AMJ.2006.20785590

Skoll Foundation. (n.d.). Connecting and Celebrating Social Entrepreneurs. Retrieved from http://www.skollfoundation.org/

Stefano, G. D., Gino, F., Pisano, G., \& Staats, B. (2014). Learning by thinking: How reflection aids performance. Working Paper No. 14-093. Boston: Harvard Business School.

Stokols, D. (2018). Social ecology in the digital age: Solving complex problems in a globalized world. London: Elsevier Academic Press.

Strauss, A., \& Corbin, J. (1990). Basics of qualitative research: Grounded theory procedures and techniques. Newbury Park: Sage.

TD Net. (2009). Transdisciplinary research. Retrieved from http://www.transdisciplinarity.ch/en/tdnet/Transdisziplinarit-t.html

Thompson, J. L. (2002). The world of the social entrepreneur. The International Journal of Public Sector Management, 15(5), 412-431. https://doi.org/10.1108/09513550210435746

Trivedi, C. (2010). Towards a social ecological framework for social entrepreneurship. Journal of Entrepreneurship, 19(1), 63-80. https://doi.org/10.1177/097135570901900104

Trivedi, C. (2013). Social entrepreneurship: Ecological consciousness and collective processes. (Order No. 3563422, University of California, Irvine). ProQuest Dissertations and Theses, 232.

Trivedi, C., \& Misra, S. (2015). Relevance of systems thinking and scientific holism to social entrepreneurship. Journal of Entrepreneurship, 24(1), 37-62. https://doi.org/10.1177/0971355714560658 
Trivedi, C., \& Stokols, D. (2011). Social enterprises and corporate enterprises: Fundamental differences and defining features Journal of Entrepreneurship, 20(1), 1-32. https://doi.org/10.1177/0971355714560658

UN News Center. (2013). World toilet day: UN urges breaking taboos, making sanitation for all a global reality. Retrieved from http://www.un.org/apps/news/story.asp?NewsID=46529

United Nations. (2015). The Millennium Development Goals Report. New York Retrieved from http://www.un.org/millenniumgoals/2015 MDG Report/pdf/MDG\%202015\%20rev\%20(July\%201).pd $\underline{f}$

United Nations Development Group. (2014). Delivering the post-2015 development agenda: Opportunities at the national and local levels. New York Retrieved from https://sustainabledevelopment.un.org/content/documents/1909UNDP-MDG-Delivering-Post-2015$\underline{\text { Report-2014.pdf }}$

Van de Ven, A. H. (1986). Central problems in the management of innovation. Management Science, 32(5), 590607. https://doi.org/10.1287/mnsc.32.5.590

Verplanken, B., \& Holland, R. W. (2002). Motivated decision making: Effects of activation and self-centrality of values on choices and behavior. Journal of Personality and Social Psychology, 82(3), 434-447. https://doi.org/10.1037/0022-3514.82.3.434

von Bertalanffy, L. (1950). The theory of open systems in physics and biology. Science, 111(2872), 23-29. https://doi.org/10.1126/science.111.2872.23

von Bertalanffy, L. (1952). Problems of life. London: Watts.

Waddock, S. A., \& Post, J. E. (1991). Social entrepreneurs and catalytic change. Public Administration Review, 51(5), 393-401. https://doi.org/10.2307/976408

Wei-Skillern, J. C., Austin, J. E., Leonard, H. B., \& Stevenson, H. H. (2007). Entrepreneurship in the social sector. Thousand Oaks, CA: Sage Publication.

Weick, K. E. (1987). Theorizing about organizational communication. In F. M. Jablin, L. L. Putnam, K. H. Roberts, \& L. W. Porter (Eds.), Handbook of organizational communication: An interdisciplinary perspective (pp. 97122). Newbury Park, CA: Sage Publications.

Weick, K. E. (1995). Sensemaking in organizations. Thousand Oaks: Sage Publications.

Weick, K. E., Sutcliffe, K. M., \& Obstfeld, D. (2005). Organizing and the process of sensemaking. Organization Science, 16(4), 409-421. https://doi.org/10.1287/orsc.1050.0133

Wilson, P. A. (1996). Empowerment: Community economic development from the inside out. Urban Studies, 33(4-5), 617-630. https://doi.org/10.1080/00420989650011753

Yunus, M., \& Jolis, A. (2007). Banker to the poor: Micro-lending and the battle against world poverty. New York: Public Affairs.

\section{BIOGRAPHIES}

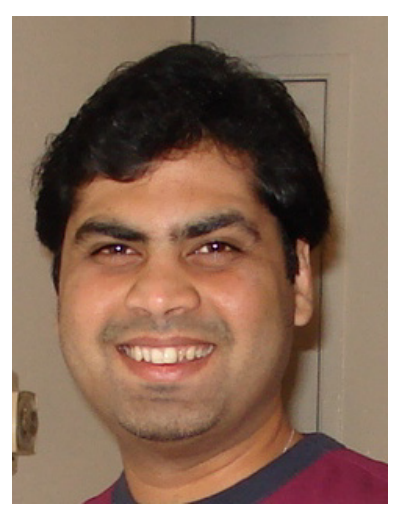

Chitvan Trivedi is an Assistant Professor in Organization and Management Studies at Gettysburg College. He holds a Ph.D. in Social Ecology from the University of California, Irvine. Prior to joining Gettysburg College, he was a postdoctoral scholar at UCI. He also holds Masters degrees in Computer Networks and Business Administration. His research focuses on social entrepreneurship and its relationship to the creation and sustenance of societal change. Specifically, he is interested in the role of systems thinking and collaborative processes in addressing social problems. His research has been supported by the Newkirk Fellowship and the Heather Mills Graduate Fellowship in Human Security at UCI. 


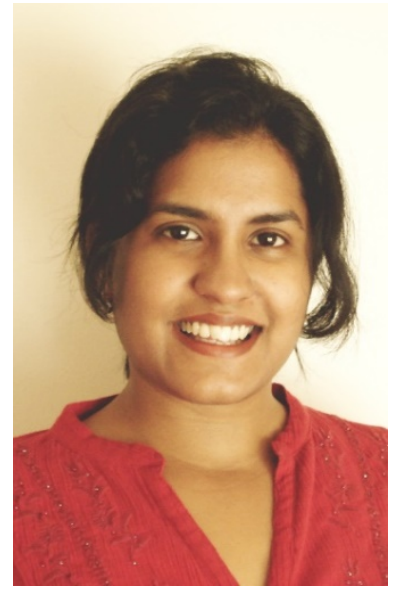

Shalini Misra is an Assistant Professor in the School of Public and International Affairs at Virginia Tech. Her research focuses on the social, psychological, and cultural implications of the Internet and mobile communication technologies; and the study of the processes and outcomes of transdisciplinary collaborative scientific, training, and action research initiatives. Key themes in her research and writing include: cognitive and health consequences of information overload and multitasking; interpersonal relationships in ubiquitous computing environments; environmental orientations, identity and sense of community in the Digital Age; contextual influences on interdisciplinary collaboration; interdisciplinary education and curriculum development; and evaluation of team science initiatives. Her research has been supported by grants from NSF, NIH, Urban Communication Foundation, Intel Digital Cultures, and the National Academies Keck Futures Initiative. She has a Ph.D. in Planning, Policy, and Design from University of California Irvine, an M.S. degree in Sustainable Resource Management (Technical University of Munich, Germany) and a B.S. degree in Civil Engineering (Gujarat University, India). 